\title{
O Estado e os \\ Bis \\ direitos \\ dos cidadãos
}

Wanderley Guilherme dos Santos*

A expansão dos direitos do 1 cidadão requer, hoje, que o Estado passe a ocupar o seu devido lugar no cenário nacional. Isso significa que a sociedade civil deve exigir a presença do Estado em áreas de onde ele tem estado ausente e a sua retirada de processos onde sua ação é indevida.

E visível que o Estado tem faltado sobretudo naquelas áreas que constituem a justificativa mais importante para a existência do próprio Estado: a produção de bens e serviços de consumo coletivo. As condiçð̃es de vida no campo, no que se refere a abastecimento de água e rede de esgotos, são bastante precárias. As melhorias relativas obsevadas entre 1970 e 1980 não foram suficientes para evitar que aumentasse o número absoluto de pessoas cujas vida e saúde estão permanentemente ameaçadas. A urbanização acelerada ocorrida no mesmo período intensificou um problema semelhante nas grandes cidades, com um número de favelas cada vez maior.

Ainda na linha de direitos funda-

- Wanderley Guilherme dos Santos é sociblogo - professor do Instituto Universittrio de Pesquisas do Rio de Janeiro (IUPERJ). mentais da cidadania encontram-se os serviços de proteção à infância, saúde pública, educação fundamental, segurança no trabalho e transporte de massa. Em todos estes itens a ação estatal é deficiente, sendo portanto responsável, em última análise, pelos elevados índices de mortalidade infantil, pelo número médio de anos de vida da população brasileira - ainda baixo e variando muito de região para região - , pelas altas taxas de analfabetismo e de acidente do trabalho e pelo desgaste e acidentes derivados do precário sistema de transportes.

A presença asfixiante e indevida do Estado manifesta-se na legislação sindical e na vida associativa em geral, na forma arbitrária de regular salários e ordenados, no monopólio da administração de fundos sociais a que os beneficiários não têm acesso (por exemplo, FGTS e PIS-PASEP). Particularmente importante para a reconquista de direitos é a libertação da vida política, quebrando todas as algemas governamentais e estatais que impedem a sociedade brasileira de se autogovernar e de submeter o Estado a seu controle. Hoje é o Estado quem controla a sociedade. Amanhã, é a sociedade que deve controlar o Estado. 
Para que o Estado venha a estar onde deve e sair de onde não deve estar, algumas condições são necessárias. Em primeiro lugar, é indispensável que os grupos sociais rompam com a antiga tradição de tudo esperar ou de tudo pedir ao Estado. $O$ que a sociedade pode decidir e resolver por si mesma não cabe ao Estado antecipar-se paternalisticamente e resolver a questão. $O$ paternalismo estatal termina sempre por obter compromissos da sociedade e, portanto, perda de direitos. A reconquista e expansão de direitos dos cidadãos exige, fundamentalmente, profunda mudança de atitude em relação ao Estado. Em segundo lugar, essa atitude nova precisa manifestar-se de forma organizada, sem o que as chances de sucesso serão mínimas.

Ideologia e organização são, portanto, dois requisitos necessários, embora não sejam suficientes, para repor o Estado em seu devido lugar. Pois é isto, essencialmente, que significa reconquistar e expandir os direitos de cidadania. 